\title{
Impact of Green Marketing on Green Consumer Behaviour
}

\author{
Dr.P.Vanishree Sah \\ CVR College Of Engineering/H\&S Department, Hyderabad, India \\ Email: pvanishree@gmail.com
}

\begin{abstract}
Green marketing is increasing globally and is influencing consumer's purchasing behaviour. Firms have started responding to environmental challenges by practicing Green Marketing strategies. Environmental Concern has become an important topic in research. The main objective of this study is to measure the impact of green marketing strategies on consumer buying behaviour. The results demonstrated that green product, green advertising, green packaging and ecolabel have significant impact on consumer buying behaviour.
\end{abstract}

Index Terms-Green Product, Green Packaging, EcoLabel, Green Advertising, Green Consumer Behaviour

\section{INTRODUCTION}

Green Marketing is designing, promoting, pricing and distributing products in a manner which promotes environmental protection and which is less detrimental to the environment. (Polonsky, 2011). Firms are adopting green marketing as a social and moral responsibility, to be more competitive, for customer satisfaction and to expand their market. Environmental awareness and concern for environment have an influence on the consumer buying behaviour. Consumers are shifting to green products to make a positive impact on the environment. Green purchase behaviour is also influenced by other factors such as social, cultural and demographic factors (Yatish Joshi, et.al, 2015). Consumers evaluate various social, environmental and individual consequences while purchasing a green product.Government regulation related to Green Marketing also help in reducing the production and consumption of harmful products.

\section{LITERATURE REVIEW}

Implementation of green marketing strategies requires huge investment in technology, and Reasearch and Development. But green marketing strategies such as ecodesign of a product, ecolabel, ecopackaging and green logo are required to face stiff competition and to have a positive impact on the customers and on the environment ( Manjunath.G, 2013). Consumers want high quality products that are environmentally safe (D'Souza, et.al., 2006). Green Corporate perception and green product value have significant influence on green purchase intention. Firms should ensure that environmental performances of their product are in accordance with customer perceived value of the green product (Collins Marfo Agyeman,(2014). Though environmental advertisement has a positive effect on consumer purchasing behaviour, an increased awareness on ecolabels would help in promoting green product consumption among consumers (Narges Delafrooz,et.al., 2014).The marketers have to focus on the demographic profile of their consumers. Most of the marketers do not consider it important while formulating green marketing strategies. But the differences in age, income, gender and literacy create a huge difference for implementation of green marketing strategies (Meghna Sharma, et.al., 2016). The designing of the green products such as packaging, labeling and quality should be in congruence with the eco concepts so that customers can associate the green products with an appropriate image (Charlie, et.al., 2014). Green marketing presents challenges because of the absence of clear understanding of the cause and effect relationships in matters affecting the environment. Since green marketing is sustainable marketing, networking resources and implementing a green strategy will be perilous (Mohammad Jalalkamali, et.al., 2016). Green perceived value has a positive influence on trust and purchase intention of the customers. Resources have to be invested in increasing the green perceived value (Chen and Chang, 2012). To cope up with health issues, climatic changes, environmental legalizations and government policies and to enhance the goodwill of the firm, it is essential to implement green marketing strategies. (Babita Saini, 2013).

\section{OBJECTIVES OF STUDY}

The main objective of the study is to measure the impact of green marketing strategies on green consumer buying behaviour. For this purpose, four green marketing strategies such as green product, green packaging, ecolabel and green advertisement were considered in this study.

\section{RESEARCH METHODOLOGY}

This study is based on the survey conducted in Hyderabad (Telangana) during June 2015-February 2016.The theoretical foundation of the study is based on various secondary sources such as texts on articles, magazines, published papers. The primary data was collected using Judgment (Purposive) sampling. The respondents were selected on the basis of judgment to include all demographic segments. The theoretical foundation of the study is based on various secondary sources such as texts on articles, magazines, published 
papers. The structured questionnaire is used to get the responses of the respondents. For the purpose of primary data collection, data were collected from 250 respondents of Hyderabad but only 219 responses came out to be relevant to the study. The data for this study were collected through the distribution of self administered questionnaires via online method (email) and offline method (hand delivery) to potential respondents across Hyderabad. The respondents were asked to express their agreement or disagreement with a statement on a fivepoint Likert type scale $(1=$ strongly disagree, $2=$ disagree, $3=$ neutral, $4=$ agree, $5=$ strongly agree). The statistical package for the Social Sciences Program (SPSS) was used in the study for statistical data analysis. Factor analysis is carried out by the researcher. A frequency distribution is used to describe the sample. For the purpose of the present study, descriptive research design and quantitative research method are used.

\section{DATA ANALYSIS AND DATA INTERPRETATION}

TABLE I

DEMOGRAPHIC FACTORS OF RESPONDENTS

\begin{tabular}{|l|l|l|}
\hline Demographic Factors & No. of Respondents & Percentage \\
\hline Age & & \\
\hline $20-30$ years & 58 & 26 \\
\hline $30-40$ years & 67 & 31 \\
\hline 41-50 years & 54 & 25 \\
\hline Above 50 years & 40 & 18 \\
\hline Gender & & \\
\hline Male & 95 & 43 \\
\hline Female & 124 & 57 \\
\hline Marital Status & & \\
\hline Single & 82 & 37 \\
\hline Married & 137 & 63 \\
\hline Profession & & \\
\hline Services & 80 & 36 \\
\hline Businessmen & 74 & 34 \\
\hline Housewife & 65 & 30 \\
\hline Annual Income(Rs) & & \\
\hline $3,00,000-5,00,000$ & 49 & 22 \\
\hline $5,00,001-7,00,000$ & 73 & 33 \\
\hline $7,00,001-9,00,000$ & 69 & 32 \\
\hline More than 9,00,000 & 28 & 13 \\
\hline
\end{tabular}

TABLE II

FACTOR LOADINGS FOR GREEN PRODUCT VARIABLES

\begin{tabular}{|l|l|}
\hline Green Product & Loadings \\
\hline Recyclable & 0.754 \\
\hline Energy Efficient & 0.788 \\
\hline Made with recycled content & 0.710 \\
\hline Biodegradable & 0.665 \\
\hline Reusable & 0.683 \\
\hline Organic & 0.796 \\
\hline Use of renewable resources in production process & 0.628 \\
\hline
\end{tabular}

The table above shows that there are positive loadings on all the green product variables. Recyclable, energy efficient, biodegradable, reusable, organic, made with recycled content, and which uses renewable resources in the production process have significant influence on green consumer behaviour. Green Product has emerged as a separate factor with an eigen value of 2.79.The above table shows that Green Product variable 'Organic', has got the highest loading of 0.796 .

TABLE III

FACTOR LOADING FOR GREEN PACKAGING VARIABLES

\begin{tabular}{|l|l|}
\hline Green Packaging & Loadings \\
\hline Use of minimal materials & 0.648 \\
\hline Energy efficient & 0.730 \\
\hline Made with Recycled content & 0.657 \\
\hline recyclability & 0.777 \\
\hline Reusable packaging & 0.762 \\
\hline Use of renewable resources in packaging & 0.591 \\
\hline $\begin{array}{l}\text { Made with Biodegradable and compostable } \\
\text { materials }\end{array}$ & 0.785 \\
\hline
\end{tabular}

The table above shows that there are positive loadings on all the green packaging variables. Energy efficient, recyclable, reusable, made with recycled content, renewable and which is made with Biodegradable and compostable materials have significant influence on green consumer behaviour. Green Packaging with an eigen value of 2.65 has also been identified as one of the important influencing factors on Green Consumer Behaviour. The above table shows that Green Packaging variable 'Made with Biodegradable and compostable materials', has got the highest loading of 0.785 .

TABLE IV

FACTOR LOADINGS FOR ECO LABEL VARIABLES

\begin{tabular}{|l|l|}
\hline Eco Label & Loadings \\
\hline Informative & 0.779 \\
\hline Trust--worthy & 0.716 \\
\hline Helps in making purchasing decisions & 0.742 \\
\hline Provides authenticity & 0.735 \\
\hline
\end{tabular}

The table above shows that there are positive loadings on all the Eco Label variables. Informative, trustworthy, authentic and which helps in making purchasing decisions have significant influence on the green consumer behaviour. EcoLabel has been identified as a separate factor with an eigen value of 2.71.The above table shows that the Eco Label variable 'Informative', has got the highest loading of 0.779 .

TABLE V

FACTOR LOADINGS FOR GREEN ADVERTISING VARIABLES

\begin{tabular}{|l|l|}
\hline Green Advertising & Loadings \\
\hline Informative & 0.725 \\
\hline Boosts confidence & 0.648 \\
\hline Reflects brand's environmental efforts & 0.690 \\
\hline Motivates pro-environmental attitudes & 0.703 \\
\hline
\end{tabular}

The table above shows that there are positive loadings on all the Green Advertising variables. Informative, boost confidence, reflecting brand's environmental efforts and which motivates proenvironmental attitudes have significant influence on the green consumer behaviour. Green Advertising has been identified as separate factor with eigen value of 2.53. The above table shows that the Green Advertising variable 'Informative' has got the highest loading of 0.724 . 
TABLE VI

FACTOR LOADINGS FOR GREEN CONSUMER BEHAVIOUR VARIABLES

\begin{tabular}{|l|l|}
\hline Green Consumer Behaviour & Loadings \\
\hline Environmental concern & 0.819 \\
\hline Environmental responsibility & 0.771 \\
\hline More Efforts to buy green products & 0.738 \\
\hline Gather information about green products & 0.799 \\
\hline Willing to pay high price for green products & 0.683 \\
\hline Recommend green products to others & 0.614 \\
\hline Willingness to pay an environmental tax & 0.607 \\
\hline Strong supporter of environmental regulation & 0.811 \\
\hline
\end{tabular}

The table above shows that there are positive loadings on all the Green Consumer Behaviour variables. Green Consumer Behaviour has been identified as a separate factor with an eigen value of 2.82 . The table above shows that the Green Advertising variable 'Informative' has got the highest loading of 0.724 .

\section{VI . CONCLUSIONS}

A company can enhance its brand image and secure its market share among the growing number of environmentally concerned consumers by adding Green Marketing to its business strategy. Green Consumers make purchase decisions based on the information about the product and the manufacturer rather than on attractive advertising campaign. Green consumers want to know the potential impact of the product on the environment after usage.

Green Consumers are giving preference to organic and energy efficient products. They consider it as their environmental responsibility to buy recyclable products. Consumers' choice for green products is influenced by the packaging too. They prefer recyclable and reusable packaging. The green consumers have to be supplied with details and authenticity on their Green claims. Though the Green consumers have environmental concern, they may not be willing to pay higher price for the green products.

Therefore the producers should not neglect the traditional consumer values of reasonable price and high quality, despite the exciting opportunities of the green consumer market.

\section{REFERENCES}

[1] Babita Saini, (2013). "Green Marketing and Its Impact on Consumer Buying Behaviour", International Journal Of Engineering Science Invention, Vol. 2, Issue 12, December 2013, pp 61-64

[2] Charlie Albert Lasuin and Ng Yuen Ching, (2014). "Factors Influencing Green Purchase Intention Among University Students", Malaysian Journal Of Business And Economics, Vol. 1, Issue 2, December 2014, pp1-4

[3] Chen, S.Y. and Chang.S.C. (2012). "Enhance Green Purchase Intention: The Roles of Green Perceived Value, Green Perceived Risk and Green Trust", Management Decision, Vol. 50, Issue 3, pp 502-520

[4] Collins Marfo Agyeman,(2014). "Consumers' Buying Behaviour Towards Green Products:An Exploratory Study",
International Journal of Management Research and Business Strategy, August 2015, Vol 3, Issue 1, pp 188-197

[5] D'Souza C, Taghian M and Khosala R (2007). "Examination of Environmental Beliefs and Consumers", Psychology and Marketing, Vol 24, Issue 5, pp 445-473

[6] Manjunath.G, (2013). "Green Marketing and Its Implementation in Indian Business Organisations", Asia

Pacific Journal Of Marketing and Management Review, Vol. 2, Issue 7, pp75-86

[7] Meghna Sharma, Prachi Trivedi, (2016). "Various Green Marketing Variables and Their Effects On Consumers' Buying Behaviour For Green Products", International Journal Of Latest Technology In Engineering, Management and Applied Science, Vol.5, Issue 1, January 2016, pp 18

[8] Mohammad Jalalkamali, Masood Forooghi, Nima Nazeri, (2016). "Green Marketing and Consumerism", International Journal Of Scientific and Technology Research, Vol. 5, Issue 1, January 2016, pp 173-178

[9] Narges Delafrooz, Mohammad Taleghani, Bahareh Nouri, (214), "Effects of Green Marketing On Consumer Purchase Behaviour", QScience Connect, Vol 2014.5 pp 29

[10] Polonsky,M.J. (2011). “Transformative Green Marketing: Impediments and Opportunities", Journal Of Business Research, Vol. 64, Issue 12, pp 1311-1319

[11] Yatish Joshi and Zillur Rehamn, (2015). "Factors Affecting Green Purchase Behaviour and Future Research Directions", International Strategic Management Review, Vol. 3, Issue 12, June-December, 2015, pp 128-143 